\title{
ENERGY REQUIREMENT AND ECONOMIC ANALYSIS OF SUBSURFACE DRIP IRRIGATION IN SIWA OASIS
}

\author{
Awady $^{1}$, M. N., M. A. Wassif ${ }^{2}$, M. F. Abd el-Salam ${ }^{3}$, and M. A. El-Farrah ${ }^{4}$
}

\section{ABSTRACT}

The aim of this investigation is to evaluate the consumed energy under surface and subsurface drip irrigation techniques in hyper arid condition of Siwa Oasis with using low quality water. Experimental treatments were done at Siwa Oasis - Matruh Governorate. The experimental results showed that energy applied efficiency (EAE, $1.75 \mathrm{~kg} / \mathrm{MJ}$ ), and without escalation (with escalation) benefit/cost ratio 6.16 (5.60) were obtained from with underneath PE sheet, at $10 \mathrm{~cm}$ dripline depth, $0.9-1.2$ $m$ dripline spacing, and VSL (two Vertically Spaced Line) arrangement.

Key words: Drip irrigation, Subsurface drip irrigation, Dripline spacing, Dripline depth, Underneath sheet, Irrigation economic analysis, Energy applied efficiency, Tomato, and Onion.

\section{INTRODUCTION}

The increased use of trickle or drip irrigation is seen as one way of helping to improve the sustainability of irrigation systems around the world. So, it is useful to get tools, which allow the maximum benefit and minimum disadvantages from these methods. The sustainability of the projects depends on the compatibility with the economic roles.

The use of saline water for agricultural irrigation is attractive for the following reasons: a) Water shortage problems can be resolved; b) Large amounts of saline water can be disposed of during the entire year, with minimal risk of groundwater deterioration; c) Economic benefits: a higher market price for the fruits, which are sweeter, and an extended shelf life, due to the stressful growing conditions (Oron et al., 1995). Using subsurface drip irrigation SDI increasers water use efficiency and its conservation, (Camp and Lamm, 2003), moreover,

(1) and (3) resp. Prof. Emerit. and Assoc. Prof., Ag. Eng. Dep., A. Shams U., Cairo, Misr (Egypt).

(2) and (4) resp. Prof.. Emerit. and Res., Soil Conserv. Dep., Desert Res. Center., Cairo, Misr (Egypt). 
using SDI enhances the emission uniformity (EU), (Aboamera, 1999), Shawky et al. (2001) and Enciso et al. (2005). Consequently, increasing EU of drip irrigation decreased the irrigation water requirements for crops. This means that saving irrigation water and energy required for irrigation could be obtained by increasing the designed water emission uniformity of trickle irrigation system, (El-Ansary et al., 1999). And this is in agreement with Keller and Bliesner (1990), Oron et al. (1995), and Bakeer (1996). The trickle irrigation has a potential for reducing pumping energy costs where operating pressure are considerably lower than that of the other pressurized systems types, (Bucks and Nakayama, 1982) and this is in agreement with Abd Elaal, (1991), who also concluded that drip irrigation system obtains higher energy application efficiency (EAE) compared to the other systems.

Low operating pressure value, where the emitter operating pressure head $5-8 \mathrm{~m}$ is suitable for fodder and vegetable production, (El-Berry, 1990). Furthermore, the converting to low-pressure emitter type may reducing irrigation consumed, (Evans et al., 1996).

Kassem and Mulhim (1999) showed that estimating net irrigation requirements are useful in determining pumping requirements, and hence the energy needs.

Barth (1995) found that the economical advantages of the SDI are savings in water and energy as well as significant improvements in crop yield. He added that the subsurface irrigation has productivity rates between 30 to $70 \%$ above surface irrigation methods. Further economic factors are influencing the social situation and minimize maintenance. Due to the subsurface layout, the laterals are not as exposed to damage and a fully mechanized labor saving operation is possible. Moreover, management problems are reduced to a minimum due to the simplicity of the system.

Effective energy use in agriculture is one of the conditions for sustainable agricultural production, since it provides financial savings, fossil resources preservation and air pollution reduction, (Pervanchon et al., 2002). Energy analysis can be divided into two parts as direct and indirect energy, (Uhlin, 1998). Direct energy is directly used at the farm and on fields for crops, but indirect energy is not directly consumed at 
the farm. However, both direct and indirect forms of energy are required for agricultural production in terms of its development and growth. On the other hand, despite its importance, energy use can be very costly. Energy input output analysis is usually used to evaluate the efficiency and environmental impacts of production systems, (Ozkan et al., 2003). Annual irrigation costs must include all costs associated with owning and/or renting, operating and maintaining the irrigation system, (Thompson et al., 1983). They also illustrated that the fixed and variable costs associated with owning and operating an irrigation system have increased for a number of years and are projected to continue to increase in the future and this known as cost escalation (inflation).

It is worth, that the ideal general planning of irrigation system consists of lateral lines and submain lines and main line and these groups come out an area, which can be repeated, (Awady, 1974).

The most economical size for irrigation main line depends only the irrigated area and not on the pipe length. A relationship was expressed in the very applicable form " $D=20.16 \sqrt{A}$ " where " $\mathrm{D}$ " is the pipe diameter in $\mathrm{mm}$ and " $\mathrm{A}$ " is the irrigated area by fed, (El Awady and Hegazi, 1987).

Another theory for selecting the optimal pipe size of trickle irrigation system based on water velocity by Hassan and Younis (1987). They found that optimal water velocity varied between $0.5-1.0,1.0-1.5$, and $0.5-1.5 \mathrm{~m} / \mathrm{s}$ for lateral, submain, and main line, respectively.

In addition, computer model can be developed to help in selecting drip irrigation optimal design. The solution based upon minimum total annual cost for specific statistical uniformity. And the availability of determining the optimal area of trickle irrigation submain unit can be obtained. It is easy to get results, which are comprehensive technical and economic details for the owner or designer about the system to evaluate the economic soundness, (Sharaf, 1996).

\section{MATERIALS AND METHODS}

\section{* Site of the experiment:}

Two field experiments were conducted during winter season (2006 - 2007) in Agricultural Experiment Station of the Desert Research Center (DRC), Siwa oasis - Mersa Matruh Governorate. Siwa depression is located on the 
northern edge of the great sand sea, one of the largest sand areas in the world in the western desert of Egypt at about $750 \mathrm{~km}$ north west of Cairo and 300 $\mathrm{km}$ west south Mersa Matruh (The Mediterranean coast). Depression has a length of about $75 \mathrm{~km}$ and a width varying between 5 and $25 \mathrm{~km}$ with a total area of about $1088 \mathrm{~km}^{2}$. The elevation of the floor is 0 to $-18 \mathrm{~m}$ from sea level and the longitude ranges between $\mathrm{E} 25^{\circ} 18^{\prime}-26^{\circ}$ and the latitude ranges between $\mathrm{N}$.

$29^{\circ} 5^{\prime}-29^{\circ} 20^{\prime}$

The soil of experiments is deeply sand. It is a part of sand dune, which is very deep and the water table surface is about $4 \mathrm{~m}$ depth.

\section{Irrigation system installation and experimental treatments:}

The first experiment $\left(\mathbf{E}_{1}\right)$ without PE foil was carried out including the following treatments:

a. Two Adjacent Lines (AL) and two Vertically-Spaced Line (VSL) at 15 $\mathrm{cm}$ in-between.

b. Variation in driplines depth ((upper dripline of VSL or AL depth was 0 and $10 \mathrm{~cm}$ ).

c. Variation in the driplines spacing (0.4 to $1.0 \mathrm{~m}$ ).

The main treatment was the driplines arrangement (AL or VSL). Submain treatments were the dripline depth $(\mathrm{D}=0$ or $10 \mathrm{~cm})$ and, variation of dripline spacing ( $\mathrm{S}$ from 0.4 to $1.0 \mathrm{~m}$ ), as shown in Fig. (1).

It is worth to mention that using $15 \mathrm{~cm}$ Vertically-Spaced driplines in VSL conforms to Ismail et al. (2006).

The second experiment $\left(\mathbf{E}_{2}\right)$ had underneath PE foil, with the following treatments:

a- Dripline arrangement (AL and VSL).

b- Variation in driplines depth (upper dripline in VSL or AL depth was varied from 0 to $25 \mathrm{~cm}$ ).

c- Variation of the driplines spacing (0.2 to $1.2 \mathrm{~m}$ ).

Each treatment was replicated two times. Each lateral dripline was considered as one replicate for the plant grown, so the plant yield of each crop was obtained from four replicates.

All plots received the same amount of organic manure (about $4 \mathrm{~m}^{3} / \mathrm{fed}$ ) without any chemical fertilizer.

The intercropping yields of tomato and onion were conducted. Tomato seedlings (Super strain B, Lycopersicon esculentum L.) with plant 
spacing $0.5 \mathrm{~m}$ of dripline and onion seedlings (Yellow creol, Allium cepa) with plant spacing $0.1 \mathrm{~m}$ of dripline, were sown on 3/1/2007. Two croppings were obtained and recorded for each experiment and each treatment.

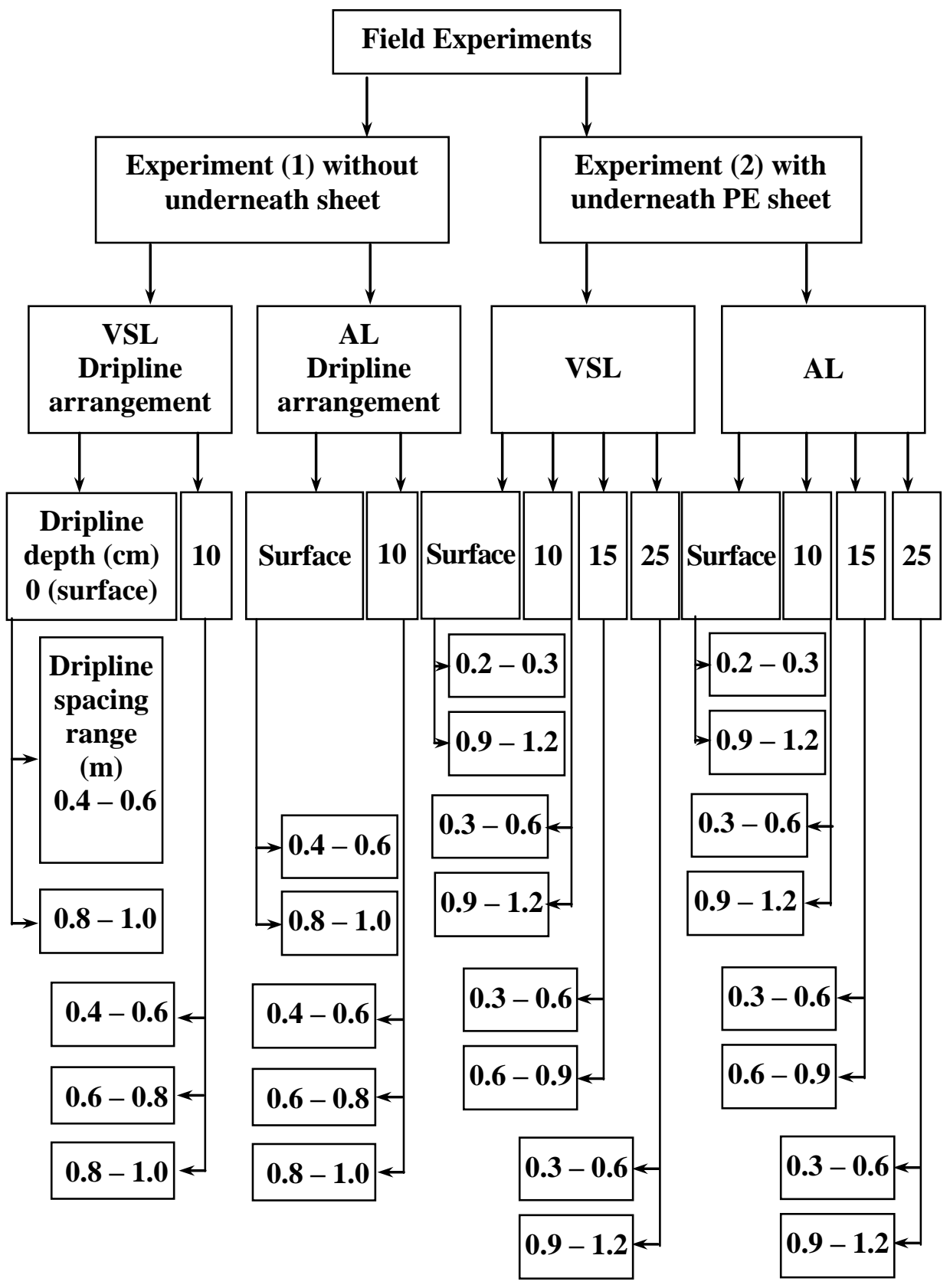

Fig. (1): Flow chart of the experimental treatments. 


\section{* Energy consumption:}

Work is required to lift and pressurized water and amount of water delivered per unit time can be related to power and the energy applied efficiency (EAE) according to Abedel-Aal (2000):

$$
B_{p}=\frac{Q \times H_{D} \times Y_{W}}{E_{i} \times E_{p} \times 1000} \ldots \ldots \ldots \ldots \ldots \ldots \ldots
$$

Where: $\mathrm{B}_{\mathrm{p}}$ : Brake power $(\mathrm{kW})$

Q : Discharge $\left(\mathrm{m}^{3} / \mathrm{sec}\right)$

$\mathrm{H}_{\mathrm{D}}$ : Total dynamic head $(\mathrm{m})$

$\mathrm{E}_{\mathrm{p}}$ : Pump efficiency

$\mathrm{Y}_{\mathrm{W}}$ : Water specific weight $\left(9810 \mathrm{~N} / \mathrm{m}^{3}\right)$

$\mathrm{E}_{\mathrm{i}}$ : Irrigation efficiency

Pumping energy requirement $\left(\mathbf{E}_{\mathbf{r}}\right)=\mathbf{B}_{\mathrm{p}} \times \mathbf{T}$

Where, T: Irrigation time per season for area unit, $(\mathrm{h} / \mathrm{fed})$

Total energy requirements, $E_{t r}(k W . h / f e d)=E_{r}+E_{\text {in }}\left(E_{t r}\right) \ldots . .(3)$ Where, $E_{\text {in }}$ Laterals installation energy consumed (MJ), and it was determined as man energy per hour equals to $1.96 \mathrm{MJ}$ according to Ozkan et al. (2003). The consumed time in the installing depends on (dripline arrangement, dripline depth, and dripline spacing).

Energy applied efficiency $($ EAE $)=\frac{\text { Total Yield }(\mathrm{kg} / \mathrm{fed})}{E_{\text {tr }}(\mathrm{kW} . \mathrm{h} / \mathrm{fed})} \ldots$

\section{* Economic analysis:}

The following equations were used to compute the annual fixed cost by the application of an amortization factor, (Thompson et al., 1983 and James, 1988). Present worth (PW) is the amount of cost that must be invested at the beginning of the analysis period. When the analysis period equals the component useful life (assumed), and it can compute by:

$$
\begin{gathered}
P W F=(1+i r)^{-L F} \ldots \ldots \ldots \ldots \ldots . . . .(5) \\
P W=(I C) \times(P W F)=I C \times(1+i r)^{-L F}
\end{gathered}
$$

The present worth value if there is salvage value at the end of useful life:

$$
P W=I C-S V\left[\frac{1+e r}{1+i r}\right]^{L F} \ldots \ldots
$$




$$
C R F=\frac{i r(1+i r)^{L F}}{(1+i r)^{L F}-1} \ldots
$$

The fixed cost for all components can compute by:

$$
A F C=C R F \sum_{c=1}^{c=n} P W_{c} \ldots \ldots
$$

The escalation effect on the present worth factor:

$$
\begin{gathered}
P W F_{(r)}=\frac{(1+e r)^{L F}}{(1+i r)^{L F}}=\left(\frac{1+e r}{1+i r}\right)^{L F} \ldots \text { (10) } \\
P W_{(r)}=(I C) \times\left(P W F_{(r)}\right)=I C \times\left(\frac{1+e r}{1+i r}\right)^{L F} \ldots(\text { 11) } \\
E A F_{(r)}=\left[\frac{(1+e r)^{L F}-(1+i r)^{L F}}{(1+e r)-(1+i r)}\right] \times\left[\frac{i r}{(1+i r)^{L F}-1}\right], \text { for er } \neq \mathrm{ir} . .
\end{gathered}
$$

Where: AFC: Annual fixed cost (amortization value)

CRF: Capital recovery factor

PWF: Present worth factor

$\mathrm{PWF}_{(\mathrm{r})}$ : Present worth factor with escalation

PW: Present worth of component "c" (L.E)

$\mathrm{PW}_{(\mathrm{r})}$ : Present worth of component with escalation "c" (L.E)

EAF: Uniform equivalent annual cost factor

EAC: Uniform equivalent annual cost.

$\mathrm{n}$ : Number of system component

LF: $\quad$ Estimated life (year)

ir: Annual interest rate (decimal)

IC: Initial cost of component or replacement cost

SV: Salvage value of component

er: Expected annual rate of cost escalation.

* Laterals and submain initial cost were estimated as follows:

$$
\begin{gathered}
I C_{L}=N \times[(L \times L U C)+(n e \times E C)] \ldots \\
I C_{S}=(N-1) \times[(S L \times S U C)+T C] \ldots \ldots
\end{gathered}
$$


Where: $\mathrm{IC}_{\mathrm{L}}$ : Lateral hose initial cost (L.E)

LUC: Price of lateral hose unit length (L.E/m)

EC: Price of emitter (L.E/unit)

$\mathrm{IC}_{\mathrm{S}}$ : Submain line initial cost (L.E)

SUC: Price of manifold unit pipe length (L.E/m)

L: $\quad$ Lateral length $(\mathrm{m})$

SL: Lateral spacing $(\mathrm{m})$

$\mathrm{N}$ : Number of laterals (unit)

ne: Number of emitters (unit)

TC: Price of grommet or tee connection (L.E/unit).

Where the emitter in the GR dripline is not a separate part and it fixed in the line then the equation (3.20) becomes as following:

$$
I C_{L}=N \times(L \times L U C)
$$

It is worth to mention that the cost of installing the irrigation system or parts can be calculated as a fixed cost and added to the total fixed cost.

The variable operation costs which contains:

- Energy cost:

$$
A E C=B p \times T_{i} \times C_{k w}
$$

Where: AEC: Annual energy cost (L.E/year)

$\mathrm{T}_{\mathrm{i}}$ : Irrigation operating time (h/year)

$\mathrm{C}_{\mathrm{kw}}$ : Cost of energy (L.E/kW.h).

\section{- Maintenance and repair cost:}

$$
\begin{gathered}
L M R=N\left(L \times L U C \times M R_{P P}\right) \ldots . .(17) \\
S M R=I C_{s} \times M R_{P P} \ldots . . .(18) \\
P M R=I C_{P} \times M R_{P} \ldots . . .(19)
\end{gathered}
$$

Where: LMR: Laterals maintenance and repair cost (L.E)

SMR: Submain line maintenance and repair cost (L.E)

PMR: Pump maintenance and repair cost (L.E)

$\mathrm{MR}_{\mathrm{PP}}$ : Annual maintenance and repair for plastic pipe (decimal)

$\mathrm{MR}_{\mathrm{P}}$ : Annual maintenance and repair for pump (decimal)

$\mathrm{IC}_{\mathrm{P}}$ : Pump initial fixed cost (L.E).

Maintenance and repair guidelines for trickle irrigation components (Jensen, 1983) showed that annual maintenance and repair ratio of initial 
cost were $3-5,5-8,1.5-2.5$, and $5-8 \%$ for centrifugal pump, diesel engine, plastic pipe, and trickle emitters, respectively.

\section{- Labor cost:}

The cost of operating time, which is consumed in operate and check the component. Labor cost is estimated by following:

$$
A L C=T_{i} \times L C \ldots \text { (20) }
$$

Where: ALC: Annual labor cost (L.E)

$\mathrm{T}_{\mathrm{i}}$ : Annual irrigation time (h/year)

LC: Labor cost (L.E/h).

\section{* Energy Applied Efficiency (EAE):}

Treatments without underneath sheet: The yield of intercropping (tomato and onion) per consumed energy for the different treatments without underneath sheet is illustrated in, Tab. (1). It is clear that the high EAE value was $0.76 \mathrm{~kg} / \mathrm{MJ}$ for all dripline spacing of dripline depth 10 $\mathrm{cm}$ under VSL.

The total seasonal energy is a part of annual energy depending on the season consumed time. Season time was $\underline{5}$ months thus the annual energy will be converted to seasonal energy per feddan. The seasonal energy was affected by the variation in treatment factors. Tab. (1), represents the total energy, and the energy components. It is clear that the highest energy component was the irrigation energy which was affected mainly by the dripline spacing then the water quantity per feddan. The energy of farmyard manure was high because it has high specific energy per weight $0.3 \mathrm{MJ} / \mathrm{kg}$, (Ozkan et al. 2003). On the other hand, the installation energy was low because it resulted from dividing the total installation energy by the component life time. The energy of harvesting and transportation depended directly on the production quantity of the treatment.

According to mean energy components, irrigation energy is the highest component followed by farmyard manure energy and the next protection of plant against sand hazards and the minimum energy value was for transportation. 
Table (1): Energy components and total energy without underneath sheet.

\begin{tabular}{|c|c|c|c|c|c|c|c|c|c|c|c|c|}
\hline $\begin{array}{c}\text { Dripline } \\
\text { arrangement }\end{array}$ & $\begin{array}{c}\text { Dripline } \\
\text { depth } \\
(\mathrm{cm})\end{array}$ & $\begin{array}{c}\text { Dripline } \\
\text { spacing } \\
\text { (m) }\end{array}$ & $\begin{array}{c}\text { Yield } \\
(\mathrm{kg} / \mathrm{fed})\end{array}$ & $\begin{array}{c}\text { Irrigation } \\
\text { energy } \\
\text { (MJ/fed) }\end{array}$ & $\begin{array}{c}\text { Installing } \\
\text { energy } \\
\text { (MJ/fed) }\end{array}$ & $\begin{array}{c}\text { Farm } \\
\text { yard } \\
\text { manure } \\
\text { energy } \\
\text { (MJ/fed) }\end{array}$ & $\begin{array}{c}\text { Protection } \\
\text { energy } \\
\text { (MJ/fed) }\end{array}$ & $\begin{array}{c}\text { Cultural } \\
\text { practices } \\
\text { energy } \\
(\mathbf{M J} / \text { fed })\end{array}$ & $\begin{array}{c}\text { Harvesting } \\
\text { energy } \\
\text { (MJ/fed) }\end{array}$ & $\begin{array}{c}\text { Transportation } \\
\text { energy } \\
\text { (MJ/fed) }\end{array}$ & $\begin{array}{c}\text { Total } \\
\text { Energy } \\
\text { (MJ/fed) }\end{array}$ & $\begin{array}{c}\text { Yield } \\
\text { energy } \\
\text { ratio } \\
(\mathrm{kg} / \mathbf{M J})\end{array}$ \\
\hline \multirow{5}{*}{ VSL } & \multirow{2}{*}{ surface } & $0.4-0.6$ & 2996 & 4964 & 38 & 501 & 305 & 261 & 48 & 28 & 6145 & 0.488 \\
\hline & & $0.8-1.0$ & 1554 & 2782 & 19 & 251 & 152 & 131 & 25 & 14 & 3374 & 0.461 \\
\hline & \multirow{3}{*}{10} & $0.4-0.6$ & 4793 & 4964 & 89 & 501 & 305 & 261 & 77 & 44 & 6241 & 0.768 \\
\hline & & $0.6-0.8$ & 3334 & 3545 & 55 & 309 & 188 & 161 & 53 & 31 & 4343 & 0.768 \\
\hline & & 0.8 - 1.0 & 2648 & 2782 & 44 & 251 & 152 & 131 & 42 & 24 & 3427 & 0.773 \\
\hline \multirow{5}{*}{$\mathbf{A L}$} & \multirow{2}{*}{ surface } & $0.4-0.6$ & 3035 & 4964 & 38 & 501 & 305 & 261 & 49 & 28 & 6146 & 0.494 \\
\hline & & $0.8-1.0$ & 1162 & 2782 & 19 & 251 & 152 & 131 & 19 & 11 & 3364 & 0.346 \\
\hline & \multirow{3}{*}{10} & $0.4-0.6$ & 2872 & 4964 & 89 & 501 & 305 & 261 & 46 & 26 & 6192 & 0.464 \\
\hline & & $0.6-0.8$ & 2741 & 3545 & 55 & 309 & 188 & 161 & 44 & 25 & 4329 & 0.633 \\
\hline & & $0.8-1.0$ & 1828 & 2782 & 44 & 251 & 152 & 131 & 29 & 17 & 3406 & 0.537 \\
\hline
\end{tabular}


EAE increased with using underneath PE sheet, where EAE value under VSL arrangement was $1.74 \mathrm{~kg} / \mathrm{MJ}$ for dripline spacing range 0.9 $1.2 \mathrm{~m}$, at $10 \mathrm{~cm}$ dripline depth, Tab. (2). The installation energy increased as compared to without underneath PE sheet due to the installing of PE sheet increasing excavation, which increases consumed energy. The highest irrigation energy was associated with dripline spacing range of $0.2-0.3 \mathrm{~m}$ due to the high amount of irrigation water per unit area compared with the other dripline spacing ranges. The protection energy is inversely proportion with dripline spacing but with small difference between the treatments.

\section{The economic analysis of irrigation system:}

The previous parts are converted here as a benefit and cost. Solving the disposal of drainage water problem in Siwa oasis has a lot of benefits, which are considered indirect benefits. This part will focus only on the direct benefits and costs. As mentioned before, the cost consists of fixed and annual (energy, maintenance and labor) costs. The calculation was based on that life time for the plastic lines (driplines) is 5 and 10 years according to exposure to sunshine. It is assumed that the annual interest rate (ir) and expected annual rate of cost escalation or inflation (er) are 10 and $8 \%$, respectively. The plastic pipe salvage equals zero prices after the useful life time. The costs of installation of the irrigation system were added to the fixed cost.

Treatments without underneath sheet: The annual cost per feddan is affected by the treatments, where the differences in the treatments led to varying the system size, and then the price. The assumed price for different fittings is shown in Table (3). The results without inflation (with inflation) without underneath sheet treatment, showed that the highest treatment costs were 7526 (12358) and 5630 (8208) L.E/year, which represent the surface driplines with spacing $0.4-0.6 \mathrm{~m}$ under AL and VSL, respectively, Fig. (9). This may be attributed to the small dripline spacing, which led to a lot of lateral dripline and big size of manifold. In addition, surface driplines led to short life time (5 years) due to sunshine (ultra violet) exposure and then enlarging the fixed cost resulted from replacing the expired parts. 
Table (2): Energy components and total energy with underneath PE sheet.

\begin{tabular}{|c|c|c|c|c|c|c|c|c|c|c|c|c|}
\hline $\begin{array}{c}\text { Dripline } \\
\text { arrangement }\end{array}$ & $\begin{array}{c}\text { Dripline } \\
\text { depth } \\
\text { (cm) }\end{array}$ & $\begin{array}{c}\text { Dripline } \\
\text { spacing } \\
(\mathrm{m})\end{array}$ & $\begin{array}{c}\text { Yield } \\
(\mathrm{kg} / \mathrm{fed})\end{array}$ & $\begin{array}{c}\text { Irrigation } \\
\text { energy } \\
\text { (MJ/fed) }\end{array}$ & $\begin{array}{c}\text { Installing } \\
\text { energy } \\
\text { (MJ/fed) }\end{array}$ & $\begin{array}{c}\text { Farm yard } \\
\text { manure } \\
\text { energy } \\
(\mathrm{MJ} / \mathrm{fed})\end{array}$ & $\begin{array}{c}\text { Protectio } \\
\text { n energy } \\
\text { (MJ/fed) }\end{array}$ & $\begin{array}{c}\text { Cultural } \\
\text { practices } \\
\text { energy } \\
\text { (MJ/fed) }\end{array}$ & $\begin{array}{c}\text { Harvestin } \\
\text { g energy } \\
(\mathrm{MJ} / \mathrm{fed})\end{array}$ & $\begin{array}{l}\text { Transporta } \\
\text { tion energy } \\
\text { (MJ/fed) }\end{array}$ & $\begin{array}{c}\text { Total } \\
\text { Energy } \\
\text { (MJ/fed) }\end{array}$ & \begin{tabular}{|c} 
Yield \\
energy \\
ratio \\
$(\mathrm{kg} / \mathbf{M J})$
\end{tabular} \\
\hline \multirow{8}{*}{ VSL } & \multirow{2}{*}{ Surface } & $0.2-0.3$ & 6555 & 9873 & 183 & 601 & 366 & 314 & 105 & 60 & 11502 & 0.57 \\
\hline & & \begin{tabular}{|l|}
0.9 \\
\end{tabular} & 1110 & 2509 & 65 & 215 & 131 & 112 & 18 & 10 & 3060 & 0.36 \\
\hline & \multirow{2}{*}{10} & $0.3-0.6$ & 5331 & 5400 & 254 & 501 & 305 & 261 & 85 & 49 & 6856 & 0.78 \\
\hline & & 0.9 - 1.2 & 5590 & 2509 & 109 & 215 & 131 & 112 & 89 & 51 & 3216 & 1.74 \\
\hline & \multirow{2}{*}{15} & $0.3-0.6$ & 5882 & 5400 & 292 & 501 & 305 & 261 & 94 & 54 & 6908 & 0.85 \\
\hline & & $0.6-0.9$ & 4052 & 3273 & 175 & 301 & 183 & 157 & 65 & 37 & 4191 & 0.97 \\
\hline & \multirow{2}{*}{25} & $0.3-0.6$ & 2917 & 5400 & 343 & 501 & 305 & 261 & 47 & 27 & 6884 & 0.42 \\
\hline & & $0.9-1.2$ & 1229 & 2509 & 147 & 215 & 131 & 112 & 20 & 11 & 3145 & 0.39 \\
\hline \multirow{8}{*}{$\mathbf{A L}$} & \multirow{2}{*}{ Surface } & \begin{tabular}{|l|}
$0.2-0.3$ \\
\end{tabular} & 4276 & 9873 & 183 & 601 & 366 & 314 & 68 & 39 & 11444 & 0.37 \\
\hline & & 0.9 - 1.2 & 2106 & 2509 & 65 & 215 & 131 & 112 & 34 & 19 & 3085 & 0.68 \\
\hline & \multirow{2}{*}{10} & $0.3-0.6$ & 6926 & 5400 & 254 & 501 & 305 & 261 & 111 & 64 & 6896 & 1.00 \\
\hline & & 0.9 - 1.2 & 2785 & 2509 & 109 & 215 & 131 & 112 & 45 & 26 & 3146 & 0.89 \\
\hline & \multirow{2}{*}{15} & 0.3 - 0.6 & 6201 & 5400 & 292 & 501 & 305 & 261 & 99 & 57 & 6916 & 0.90 \\
\hline & & $0.6-0.9$ & 1659 & 3273 & 175 & 301 & 183 & 157 & 27 & 15 & 4130 & 0.40 \\
\hline & \multirow{2}{*}{25} & $0.3-0.6$ & 3497 & 5400 & 343 & 501 & 305 & 261 & 56 & 32 & 6898 & 0.51 \\
\hline & & $0.9-1.2$ & 1080 & 2509 & 147 & 215 & 131 & 112 & 17 & 10 & 3141 & 0.34 \\
\hline
\end{tabular}


The variation in the cost value between the two arrangement VSL and AL according to the VSL arrangement has one dripline on the surface and another subsurface, while in AL arrangement both driplines were at the surface. In contrast, minimum treatment costs were 2333 (2566) and 2366 (2599) L.E/year under $10 \mathrm{~cm}$ dripline depth with $0.8-1.0 \mathrm{~m}$ dripline spacing under AL and VSL, respectively. This is attributed to that price of installing VSL laterals was higher than that of AL at the same depth because the total depth in VSL was deeper than that in AL by $15 \mathrm{~cm}$.

The total season cost is a part of annual cost depending on the season consumed time. Season time was $\underline{5}$ month thus the annual cost will be converted to season cost per feddan. The season cost is affected by the variation in treatments. Tab. (4) represents the benefits of intercropping yields, total cost, and the cost components in the case without inflation. It is clear that the highest cost component was the fixed cost in all treatments.

Table (3): The assumed price for irrigation system fittings and crop in 2006.

\begin{tabular}{|c|c|c|c|}
\hline Fitting & $\begin{array}{c}\text { Dia. } \\
(\mathrm{mm})\end{array}$ & Unit & $\begin{array}{l}\text { Price } \\
\text { (L.E) }\end{array}$ \\
\hline \multirow{6}{*}{ Plastic pipes (PVC) } & 50 & $\mathrm{~m}$ & 4.4 \\
\hline & 63 & $\mathrm{~m}$ & 5.8 \\
\hline & 110 & $\mathrm{~m}$ & 17 \\
\hline & 125 & $\mathrm{~m}$ & 21 \\
\hline & 140 & $\mathrm{~m}$ & 25 \\
\hline & 160 & $\mathrm{~m}$ & 35.45 \\
\hline GR lateral & 16 & $\mathrm{~m}$ & 0.6 \\
\hline Total length of pipe $(\mathrm{m})$ in Ex. station & 125 & $\mathrm{~m}$ & 703 \\
\hline Total experimental serviced area (fed) & & fed & 25 \\
\hline Related part with fed & 125 & & 28.12 \\
\hline Price of Pump & & No. & 20000 \\
\hline Related price part with fed (pump) & & & 800 \\
\hline \multicolumn{4}{|l|}{ Energy price: } \\
\hline $1 \mathrm{~kW} . \mathrm{h}$ & & kW.h & 0.066 \\
\hline \multicolumn{4}{|l|}{ Crop price: } \\
\hline Tomato & & $\mathrm{kg}$ & 1 \\
\hline Onion & & $\mathrm{kg}$ & 1 \\
\hline
\end{tabular}


Table (4): Cost components, total cost, the benefit of treatments without underneath sheet at year's 2006.

\begin{tabular}{|c|c|c|c|c|c|c|c|c|c|c|c|}
\hline \multirow[b]{2}{*}{ Escalate } & \multirow{2}{*}{$\begin{array}{c}\text { Dripline } \\
\text { arrangement }\end{array}$} & \multirow{2}{*}{$\begin{array}{c}\text { Dripline } \\
\text { Depth } \\
(\mathrm{cm})\end{array}$} & \multirow{2}{*}{$\begin{array}{c}\text { Dripline } \\
\text { spacing } \\
(\mathrm{m})\end{array}$} & \multicolumn{5}{|c|}{ Cost L.E/season } & \multirow{2}{*}{$\begin{array}{c}\text { Benefit } \\
\text { (L.E/season) }\end{array}$} & \multirow[b]{2}{*}{ Ratio } & \multirow{2}{*}{$\begin{array}{c}\text { System cost } \\
\text { (L.E/year) }\end{array}$} \\
\hline & & & & Fixed & Energy & Maintenance & Labor & Total & & & \\
\hline \multirow{10}{*}{ Without } & \multirow{5}{*}{ VSL } & \multirow{2}{*}{ Surface } & $0.4-0.6$ & 1971 & 91 & 190 & 94 & 2346 & 2996 & 1.28 & 5630 \\
\hline & & & \begin{tabular}{|c|}
$0.8-1.0$ \\
\end{tabular} & 1159 & 51 & 122 & 94 & 1426 & 1554 & 1.09 & 3422 \\
\hline & & \multirow{3}{*}{10} & $0.4-0.6$ & 1172 & 91 & 190 & 94 & 1547 & 4793 & 3.10 & 3713 \\
\hline & & & \begin{tabular}{|l|}
0.6 \\
\end{tabular} & 832 & 65 & 139 & 94 & 1130 & 3334 & 2.95 & 2712 \\
\hline & & & \begin{tabular}{|c|}
$0.8-1.0$ \\
\end{tabular} & 719 & 51 & 122 & 94 & 986 & 2648 & 2.69 & 2366 \\
\hline & \multirow{5}{*}{$\mathbf{A L}$} & \multirow{2}{*}{ surface } & $0.4-0.6$ & 2761 & 91 & 190 & 94 & 3136 & 3035 & 0.97 & 7526 \\
\hline & & & \begin{tabular}{|c|}
$0.8-1.0$ \\
\end{tabular} & 1598 & 51 & 122 & 94 & 1865 & 1162 & 0.62 & 4476 \\
\hline & & \multirow{3}{*}{10} & $0.4-0.6$ & 1155 & 91 & 190 & 94 & 1530 & 2872 & 1.88 & 3672 \\
\hline & & & $0.6-0.8$ & 815 & 65 & 139 & 94 & 1113 & 2741 & 2.46 & 2671 \\
\hline & & & \begin{tabular}{|c|}
$0.8-1.0$ \\
\end{tabular} & 705 & 51 & 122 & 94 & 972 & 1828 & 1.88 & 2333 \\
\hline \multirow{10}{*}{ With } & \multirow{5}{*}{ VSL } & \multirow{2}{*}{ Surface } & $0.4-0.6$ & 2908 & 125 & 259 & 128 & 3420 & 2996 & 0.88 & 8208 \\
\hline & & & $0.8-1.0$ & 1681 & 69 & 167 & 128 & 2045 & 1554 & 0.76 & 4908 \\
\hline & & \multirow{3}{*}{10} & $0.4-0.6$ & 1172 & 125 & 259 & 128 & 1684 & 4793 & 2.85 & 4042 \\
\hline & & & $0.6-0.8$ & 832 & 89 & 189 & 128 & 1238 & 3334 & 2.69 & 2971 \\
\hline & & & \begin{tabular}{|c|}
$0.8-1.0$ \\
\end{tabular} & 719 & 69 & 167 & 128 & 1083 & 2648 & 2.45 & 2599 \\
\hline & \multirow{5}{*}{$\mathbf{A L}$} & \multirow{2}{*}{ surface } & $0.4-0.6$ & 4637 & 125 & 259 & 128 & 5149 & 3035 & 0.59 & 12358 \\
\hline & & & \begin{tabular}{|l|}
$0.8-1.0$ \\
\end{tabular} & 2644 & 69 & 167 & 128 & 3008 & 1162 & 0.39 & 7219 \\
\hline & & \multirow{3}{*}{10} & $0.4-0.6$ & 1155 & 125 & 259 & 128 & 1667 & 2872 & 1.72 & 4001 \\
\hline & & & $0.6-0.8$ & 815 & 89 & 189 & 128 & 1221 & 2741 & 2.24 & 2930 \\
\hline & & & $0.8-1.0$ & 705 & 69 & 167 & 128 & 1069 & 1828 & 1.71 & 2566 \\
\hline
\end{tabular}


The season cost is affected by inflation plus the variation in treatments. Tab. (4) represents the benefits and cost components. It is clear that the inflation enlarges the fixed cost especially in the surface treatments in both AL and VSL.

According to mean cost components, fixed cost is the highest component followed by maintenance cost and next the labor cost and at last the energy cost. It is clear that the inflation effects proportional with the component value.

The benefit from crops yield per total cost ratio is shown in Tab. (4). Dripline depth of $10 \mathrm{~cm}$ shows superiority in both VSL and AL. These results are in agreement with Keller and Bliesner (1990), Barth (1995), and Oron et al. (1995). Without inflation (with inflation) high profit ratio values were 2.69 (2.45), 2.95 (2.69), and 3.10 (2.85) for dripline spacing ranges $0.8-1.0,0.6-0.8$, and $0.4-0.6 \mathrm{~m}$, respectively with $10 \mathrm{~cm}$ dripline depth and under VSL. The surface driplines gave low ratio values in both arrangements.

In the treatment of with underneath PE sheet, the highest treatment costs without inflation (with inflation) were 13961 (25646) and 10102 (15122) L.E/year, which represent the surface driplines with dripline spacing range $0.2-0.3 \mathrm{~m}$ under AL and VSL, respectively, Tabs. (5 and 6). This may be attributed, as mentioned previously to replacement costs of laterals for surface case. In contrast, minimum costs were 2124 (2342) and 2179 (2397) L.E/year, under $10 \mathrm{~cm}$ dripline depth, with $0.9-1.2 \mathrm{~m}$ dripline spacing, and under AL and VSL, respectively. It is clear that the highest component cost was the fixed cost followed by maintenance cost, next the labor cost and last the energy cost. In addition, the inflation enlarges the fixed cost, especially in the surface treatments in both AL and VSL arrangement.

The benefit price from crops yield per total cost ratio is shown in Tabs. (5 and 6). Dripline depth of $10 \mathrm{~cm}$ was superior in both VSL and AL arrangement. The highest profit ratio without inflation (with inflation) were 3.54 (3.26), 3.69 (3.37), and 6.16 (5.60) for dripline spacing ranges $0.3-0.6,0.6-0.9$, (15 cm dripline depth), and $0.9-1.2 \mathrm{~m}(10 \mathrm{~cm}$ dripline depth), respectively under VSL arrangement. 
Table (5): Cost components, total cost, the benefit of treatments with PE underneath sheet without inflation at year's 2006.

\begin{tabular}{|c|c|c|c|c|c|c|c|c|c|c|}
\hline \multirow{2}{*}{$\begin{array}{c}\text { Dripline } \\
\text { arrangement }\end{array}$} & \multirow{2}{*}{$\begin{array}{c}\text { Dripline } \\
\text { depth }(\mathrm{cm})\end{array}$} & \multirow{2}{*}{$\begin{array}{c}\text { Dripline } \\
\text { spacing } \\
\text { (m) }\end{array}$} & \multicolumn{5}{|c|}{ Cost L.E/season } & \multirow{2}{*}{$\begin{array}{c}\text { Benefit } \\
\text { (L.E/season) }\end{array}$} & \multirow[b]{2}{*}{ Ratio } & \multirow{2}{*}{$\begin{array}{r}\text { System cos } \\
\text { (L.E/year) }\end{array}$} \\
\hline & & & Fixed & Energy & Maintenance & Labor & Total & & & \\
\hline \multirow{8}{*}{ VSL } & \multirow{2}{*}{ surface } & $0.2-0.3$ & 3617 & 181 & 317 & 94 & 4209 & 6555 & 1.56 & 10102 \\
\hline & & $0.9-1.2$ & 1046 & 46 & 110 & 94 & 1296 & 1110 & 0.86 & 3110 \\
\hline & \multirow{2}{*}{10} & $0.3-0.6$ & 1260 & 99 & 202 & 94 & 1655 & 5331 & 3.22 & 3972 \\
\hline & & $0.9-1.2$ & 658 & 46 & 110 & 94 & 908 & 5590 & 6.16 & 2179 \\
\hline & \multirow{2}{*}{15} & $0.3-0.6$ & 1265 & 99 & 202 & 94 & 1660 & 5882 & 3.54 & 3984 \\
\hline & & $0.6-0.9$ & 811 & 60 & 133 & 94 & 1098 & 4052 & 3.69 & 2635 \\
\hline & \multirow{2}{*}{25} & $0.3-0.6$ & 1293 & 99 & 202 & 94 & 1688 & 2917 & 1.73 & 4051 \\
\hline & & $0.9-1.2$ & 669 & 46 & 110 & 94 & 919 & 1229 & 1.34 & 2206 \\
\hline \multirow{8}{*}{$\mathbf{A L}$} & \multirow{2}{*}{ surface } & $0.2-0.3$ & 5225 & 181 & 317 & 94 & 5817 & 4276 & 0.74 & 13961 \\
\hline & & $0.9-1.2$ & 1034 & 46 & 110 & 94 & 1284 & 2106 & 1.64 & 3082 \\
\hline & \multirow{2}{*}{10} & $0.3-0.6$ & 1243 & 99 & 202 & 94 & 1638 & 6926 & 4.23 & 3931 \\
\hline & & $0.9-1.2$ & 635 & 46 & 110 & 94 & 885 & 2785 & 3.15 & 2124 \\
\hline & \multirow{2}{*}{15} & $0.3-0.6$ & 1254 & 99 & 202 & 94 & 1649 & 6201 & 3.76 & 3958 \\
\hline & & $0.6-0.9$ & 797 & 60 & 133 & 94 & 1084 & 1659 & 1.53 & 2602 \\
\hline & \multirow{2}{*}{25} & $0.3-0.6$ & 1265 & 99 & 202 & 94 & 1660 & 3497 & 2.11 & 3984 \\
\hline & & 0.9 - 1.2 & 658 & 46 & 110 & 94 & 908 & 1080 & 1.19 & 2179 \\
\hline
\end{tabular}


Table (6): Cost components, total cost, the benefit of treatments with PE underneath sheet with inflation.

\begin{tabular}{|c|c|c|c|c|c|c|c|c|c|c|}
\hline \multirow{2}{*}{$\begin{array}{c}\text { Dripline } \\
\text { arrangement }\end{array}$} & \multirow{2}{*}{$\begin{array}{c}\text { Dripline } \\
\text { depth } \\
\text { (cm) }\end{array}$} & \multirow{2}{*}{$\begin{array}{c}\text { Dripline } \\
\text { spacing } \\
\text { (m) }\end{array}$} & \multicolumn{5}{|c|}{ Cost L.E/season } & \multirow{2}{*}{$\begin{array}{c}\text { Benefit } \\
\text { (L.E/season) }\end{array}$} & \multirow{2}{*}{ Ratio } & \multirow{2}{*}{$\begin{array}{r}\text { System cos } \\
\text { (L.E/year) }\end{array}$} \\
\hline & & & Fixed & Energy & Maintenance & Labor & Total & & & \\
\hline \multirow{8}{*}{ VSL } & \multirow{2}{*}{$\mathbf{0}$} & $0.2-0.3$ & 5494 & 247 & 432 & 128 & 6301 & 6555 & 1.04 & 15122 \\
\hline & & $0.9-1.2$ & 1515 & 63 & 150 & 128 & 1856 & 1110 & 0.60 & 4454 \\
\hline & \multirow{2}{*}{10} & $0.3-0.6$ & 1260 & 135 & 275 & 128 & 1798 & 5331 & 2.96 & 4315 \\
\hline & & $0.9-1.2$ & 658 & 63 & 150 & 128 & 999 & 5590 & 5.60 & 2398 \\
\hline & \multirow{2}{*}{15} & $0.3-0.6$ & 1265 & 135 & 275 & 128 & 1803 & 5882 & 3.26 & 4327 \\
\hline & & $0.6-0.9$ & 811 & 82 & 182 & 128 & 1203 & 4052 & 3.37 & 2887 \\
\hline & \multirow{2}{*}{25} & $0.3-0.6$ & 1293 & 135 & 275 & 128 & 1831 & 2917 & 1.59 & 4394 \\
\hline & & $0.9-1.2$ & 669 & 63 & 150 & 128 & 1010 & 1229 & 1.22 & 2424 \\
\hline \multirow{8}{*}{$\mathbf{A L}$} & \multirow{2}{*}{$\mathbf{0}$} & $0.2-0.3$ & 9879 & 247 & 432 & 128 & 10686 & 4276 & 0.40 & 25646 \\
\hline & & $0.9-1.2$ & 1503 & 63 & 150 & 128 & 1844 & 2106 & 1.14 & 4426 \\
\hline & \multirow{2}{*}{10} & $0.3-0.6$ & 1243 & 135 & 275 & 128 & 1781 & 6926 & 3.889 & 4274 \\
\hline & & $0.9-1.2$ & 635 & 63 & 150 & 128 & 976 & 2785 & 2.85 & 2342 \\
\hline & \multirow{2}{*}{15} & $0.3-0.6$ & 1254 & 135 & 275 & 128 & 1792 & 6201 & 3.46 & 4301 \\
\hline & & $0.6-0.9$ & 797 & 82 & 182 & 128 & 1189 & 1659 & 1.40 & 2854 \\
\hline & \multirow{2}{*}{25} & $0.3-0.6$ & 1265 & 135 & 275 & 128 & 1803 & 3497 & 1.94 & 4327 \\
\hline & & $0.9-1.2$ & 658 & 63 & 150 & 128 & 999 & 1080 & 1.08 & 2398 \\
\hline
\end{tabular}




\section{SUMMARY AND CONCLUSIONS}

In case of with underneath PE sheet, EAE, the highest value under VSL was $1.75 \mathrm{~kg} / \mathrm{MJ}$ for dripline spacing range $0.9-1.2 \mathrm{~m}$, at $10 \mathrm{~cm}$ dripline depth.

In the treatments without underneath sheet, the minimum cost without inflation (with inflation) was 2333 (2566) L.E/year under $10 \mathrm{~cm}$ dripline depth with $0.8-1.0 \mathrm{~m}$ dripline spacing under AL. According to mean cost components, fixed cost had the highest contribution, followed by maintenance cost, labor cost, and at last the energy cost.

From the benefit cost (profit) ratio point of view, $10 \mathrm{~cm}$ dripline depth had high ratio at any width either for VSL or AL arrangement. The highest profit ratio without inflation (with inflation) was 3.10 (2.85) for dripline spacing range $0.4-0.6 \mathrm{~m}$, with $10 \mathrm{~cm}$ dripline depth under VSL arrangement.

In the treatments with underneath PE sheet, the minimum cost without inflation (with inflation) was 2124 (2342) L.E/year, under $10 \mathrm{~cm}$ dripline depth, with $0.9-1.2 \mathrm{~m}$ dripline spacing, under AL. It is clear that the escalation enlarges the fixed cost especially in the surface treatments in both AL and VSL.

From the benefit cost ratio point of view, $10 \mathrm{~cm}$ dripline depth had high ratio at any width either for VSL or AL arrangement. The highest ratio values were 6.16 (5.60) without and with inflation for dripline spacing range $0.9-1.2 \mathrm{~m}$, with $10 \mathrm{~cm}$ dripline depth under VSL arrangement.

\section{REFERENCES}

Abd Elaal, S. E. (1991). Study on selecting the proper system of irrigation new lands. M. Sc. Thesis, Fac. of Agric. Zagazig Univ.: 89 p.

Abdel-Aal, EL. I. (2000). Effect of some parameters of trickle irrigation system on pea production. Misr J. Agric. Eng. 17 (1): 113 - 124 p.

Aboamera, M. A. (1999). Performance of subsurface drip irrigation in sandy soil under different lateral depths. Misr J. Agric. Eng., 16(3): $612-624 \mathrm{p}$.

Awady, M. N. (1974). Leaky irrigation method., Engineering J., 5 (September - October): $45-50$ p. 
Bakeer, G. A. (1996). The effect of applying drip irrigation system under certain environmental resources on soil productivity deterioration at North Sinai. Misr J. Agric. Eng., 13(2): 305 - 325 p.

Barth H. K. (1995). Resource conservation and preservation through a new subsurface irrigation system. In Proceedings of the Fifth International Microirrigation Congress. April 2-6, Orlando, Florida. ASAE, 2950 Niles Rd., St. Joseph, MI 49085-9659: 168 - 174 p.

Bucks, D. A. and F. S. Nakayama (1982). Principles, and potentialities of trickle (drip) irrigation. In: Advances in irrigation, D. Hillel (Ed.). 219 - 289, Academic Press, New York, USA.

Camp, C. R. and F. R. Lamm (2003). Irrigation system, subsurface drip. Publication by Marcel Dekker, Inc. Encyclopedia of Water Science DOI: 10.1081/E-EWS 120010066. 560 - 564 p.

El-Ansary, M. Y.; M. A. Awad; M. N. Awady, and A. H. El-Eryani (1999). Effect of drip irrigation uniformity on crop production. The $7^{\text {th }}$ Conference of Misr Society of Agric. Eng., 27-28 October $1999,320-330 \mathrm{p}$.

El Awady, M. N. and M. M. Hegazi (1987). The most economical size for irrigation pipes., Mansura U., Conf. Agric. Sc., Food Deficiency Overcoming. Autonomous Efforts in Egypt, 22-24 June, 1987, 2: $422-429$ p.

El-Berry, A. M. (1990). Study on the performance of Bi-wall irrigation tubes. Misr J. Agric. Eng., 7 (1): 25 - 39 p.

Enciso, J.; J. Jifon, and B. Wiedenfeld (2005). Subsurface drip irrigation of onions: Effects of emitter spacing and drip depth on yield. ASAE Annual international Tampa, Florida, 17-20 July 2005, Paper Number: 052242:1-7 p.

Evans, R.; R. E. Sneed, and J. H. Hunt (1996). Irrigation management strategies to improve water and energy use efficiencies. North Carolina Cooperative Exten. Serv., AG 425-5.

Hassan, M. H. and S. M. Younis (1987). Pipe selection in relation to energy consumption under drip irrigation system. Misr J. Agric. Eng., 4 (2): 175 - 201 p. 
Ismail, S. M.; T. K. Zien El-Abedin; T. K. Wassif, and M. N. El-Nesr (2006). Wetting pattern simulation of surface and subsurface drip irrigation system, II-Model, validation and analysis. The $14^{\text {th }}$ Annual Conf. Misr Soc. Agric. Eng. "New Trends in Agricultural Engineering" 2 Nov. 2006. Misr J. Eng., 23 (4): 1035 - 1057 p.

James, L. G. (1988). Principles of farm irrigation system design. John Wiley \& Sons, Inc.:543 p.

Kassem, A. S. and F. N. Mulhim (1999). Estimationg irrigation water and energy needs for Egypt. Misr. J. Agric. Eng., 16 (2) 352 - 362 p.

Keller, J. and R. D. Bliesner (1990). Sprinkle and trickle irrigation. Chapman and Hall Pub. 115 Fifth Avenue New York, NY 1003. 522 - $551 \mathrm{p}$.

Oron, G.; Y. DeMalach; L. Gillerman, and I. David (1995). Pear response to saline water application under subsurface drip irrigation. In Proc. $5^{\text {th }}$ I. Microir. Congr. April 2-6, Orlando, Florida. ASAE, 2950 Niles Rd., St. Joseph, MI 49085-9659: 97 103p.

Ozkan, B.; H. Akcaoz, and F. Karadeniz (2003). Energy requirement and economic analysis of citrus production in Turkey. Faculty of Agriculture, Department of agricultural economics, University of Akdeniz, Antalay 0707, Turkey: 1-10 p.

Pervanchon, F.; C. Bockstaller, and P. Girardin (2002). Assessment of energy use in arable farming systems by means of an agroecological indicator: the energy indicator. Agric. Syst. 2002; 72: $149-172 \mathrm{p}$.

Sharaf, G. A. (1996). Optimal design of trickle irrigation submain-unit. Misr J. Ag. Eng., 13 (3): $501-515$ p.

Shawky, M. E.; F. A. Goman; G. A. Bakeer, and A. S. Mostafa (2001). Actual and calculated irrigation water requirement of green bean crop under different irrigation system in Egypt. Misr J. Agric. Eng., 18 (3): $511-526$.

Thompson, G. T.; L. B. Spiess, and J. N. Krider (1983). Farm resources and system selection. Chapter 3 In: M. E. Jensen (Ed.): 
Design and operation of farm irrigation systems. ASAE Monograph No. 3: $45-73$ p.

Uhlin, H. (1998). Why energy productivity is increasing: an I-O analysis of Swedish agriculture. Agric. Syst 1988: 56 (4): 443 - 465 p.

\section{الملخص العربيى}

\section{إحتياجات الطاقة والإقتصاديات لنظام الري بالتتقيط تحت السطحي بواحة سيوة}

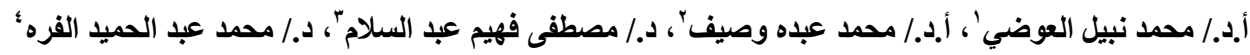
أجري هذا البحث بمحطة مركز بحوث الصحر اء بو احة سيوة - محافظة مطروح، بهدف دراسة التقييم الطاقي والاقتصادي لإستخدام نظام التنقيط تحت السطحي تحت نأثثر الأبعاد الهندسية المختلفة لنظام الري في ظروف الواحة ومع إستخدام مياه ذات ملوحة عالية (حوالي لـ ...

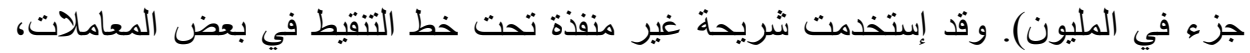

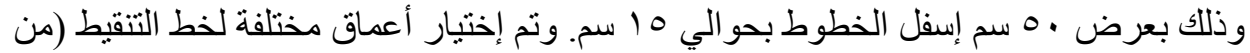

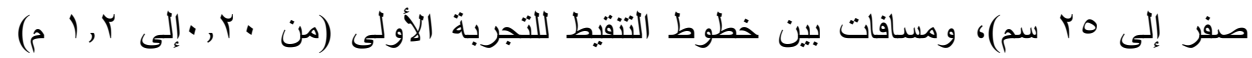
وللتجربة الثانية (من ع, · إلى • , ا م). و أخذ توزيع الرطوبة في قطاع التربة على عمق واحد

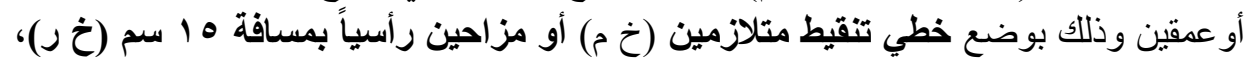
وقيس الناتج المحصولي لكل من الطماطم و البصل، و المنزر عا بأرض رضم رملية، وذللك باستخدام

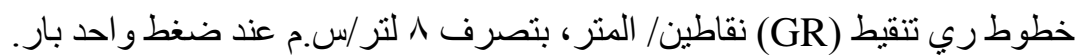
وقد توصلت الدر اسة إلى النتائج الآتية:

* كفاءة تطبيق الطاقة (EAE):

ـ تـأثرت قيمـة النـاتج المحصـولي بالنسبة للطاقـة المستـهكة (EAE) لمحصدولي الطمـاطم و البصـل بعمق خطوط التنقيط، وترتيب الخطوط وكذللك وجود حـاجز تحت التربـة من عدمها، ففي حالـة عدم

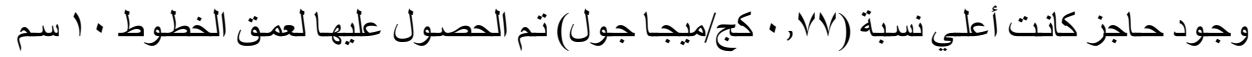

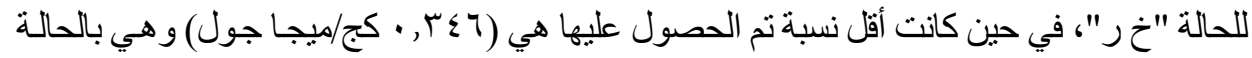

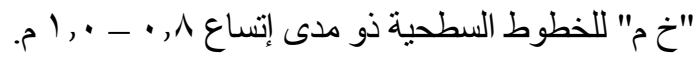

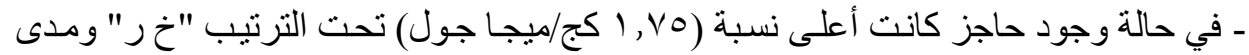

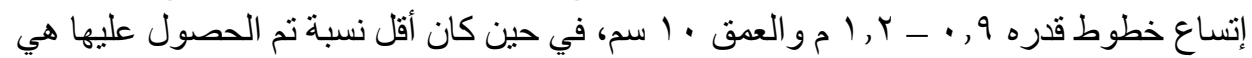

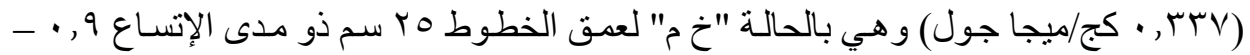

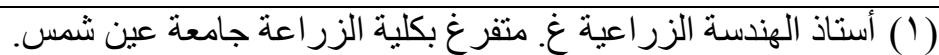

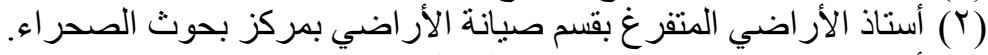

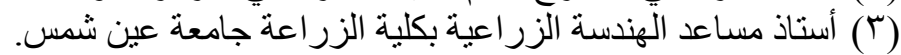

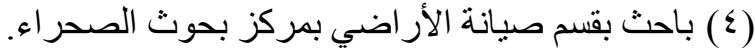




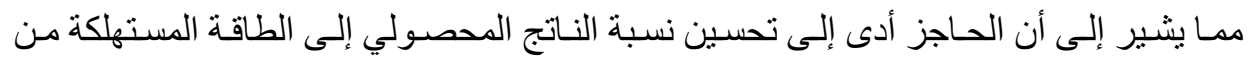
oV

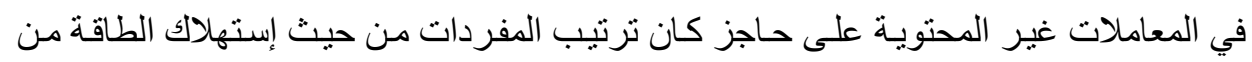

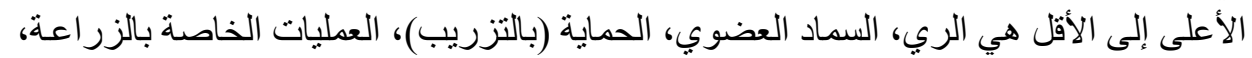

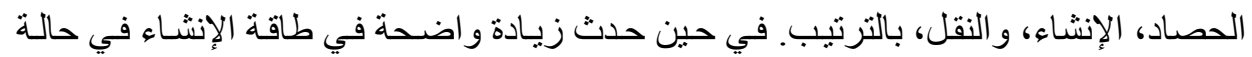
وجود عازل نتيجة زيادة العمق و الإتساع للحفر. وقد إرتبطت طاقة الري و عملية الحمايـة بالإتسـاع بين خطوط التنقيط في حين إرتبطت طاقة الإنثـاء بعمث و إتساع الحفر وكنللك إرتنطت طاقة الحصاد و النقل بكمية الإنتاج.

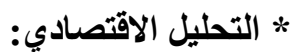

وقد تضمنت التكلفة السنوية لنظام الري و الذي تأثر بالمعاملات تحت الدر اسة، حيث يؤدي تغيير

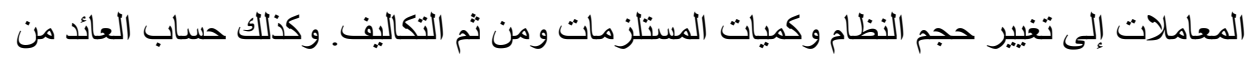
المحصول في الموسم و التكاليف للموسم نسبةًً إلى السنة. و هذه التكاليف سو اء ثابتة أو متغيرة لازمة لامتلاك وتشغيل أنظمة الري و التي تستمر للعديد من السنوات، و عند التخطيط لتغطية هذه فئه

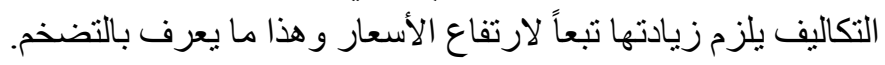

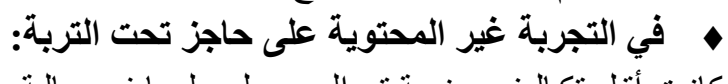

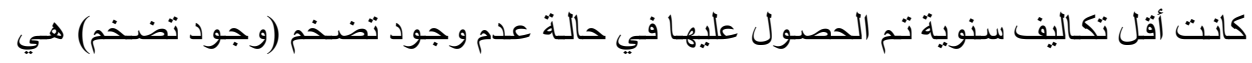

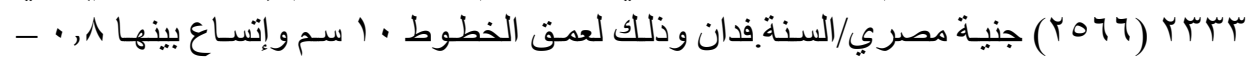

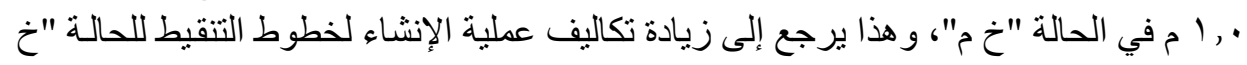

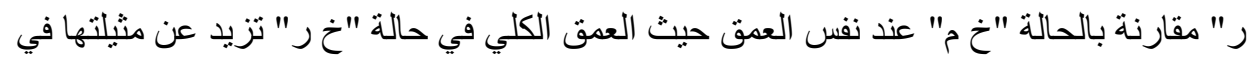

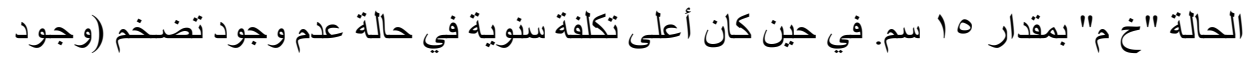

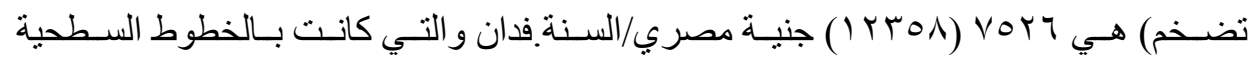

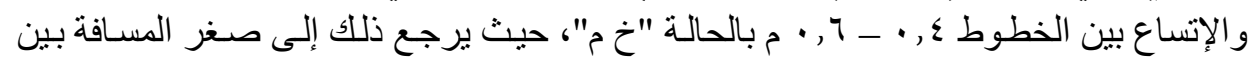

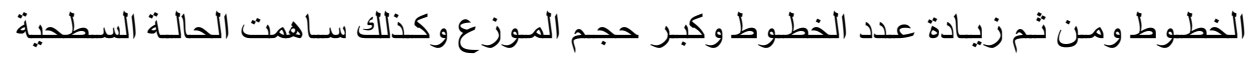

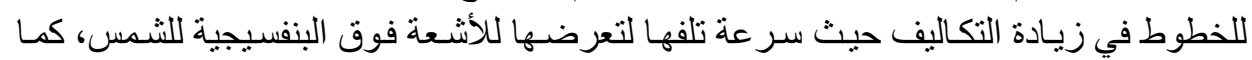

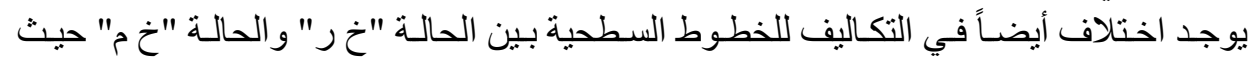

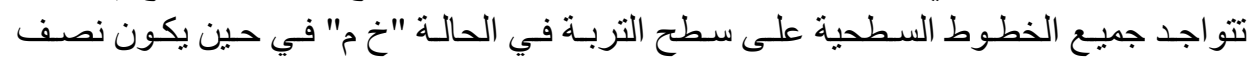

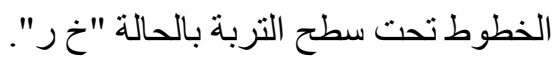

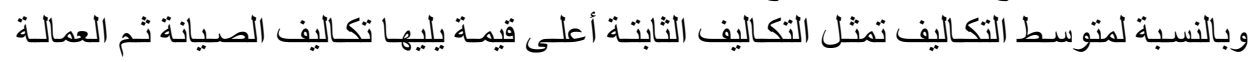
و وأخر ها تكاليف الطاقة.

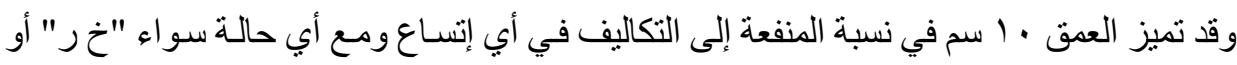

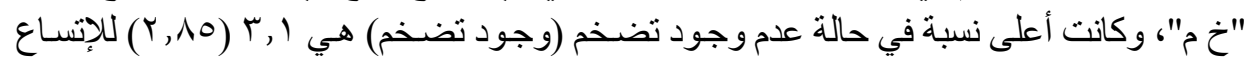

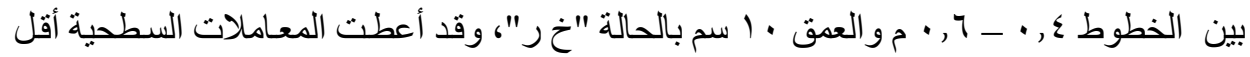




\section{في التجربة المحتوية على حاجز تحت التربة:}

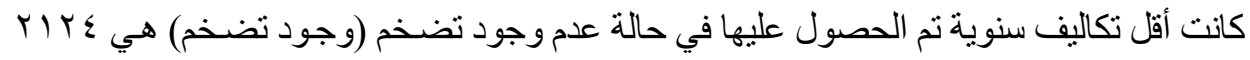

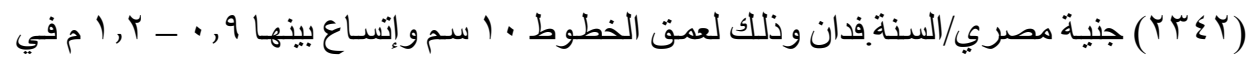

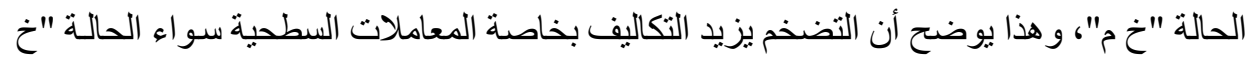

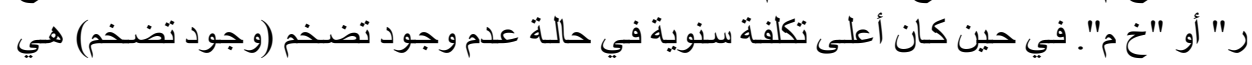

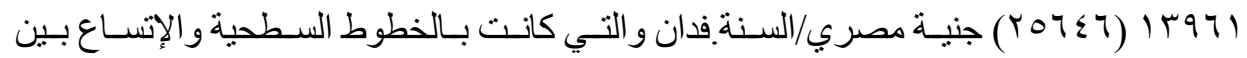

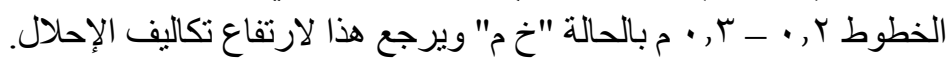

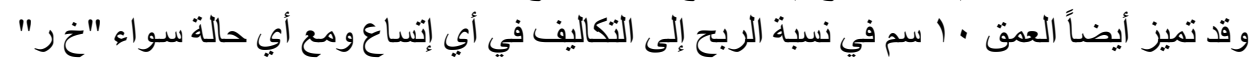

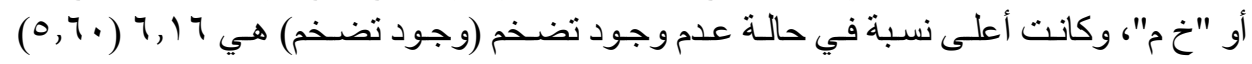

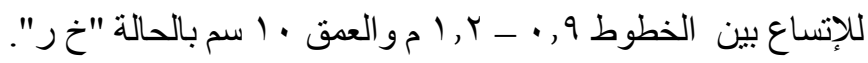

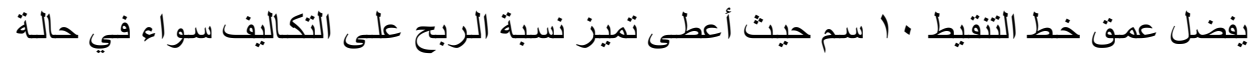

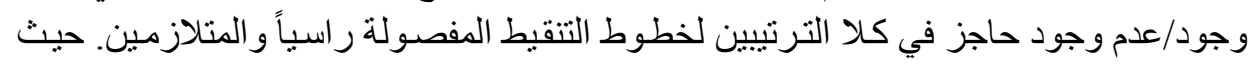

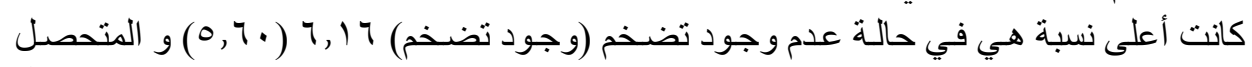

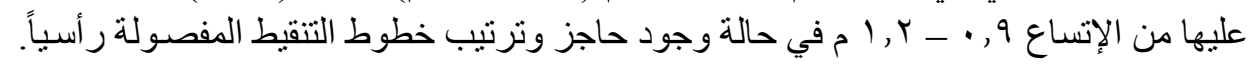

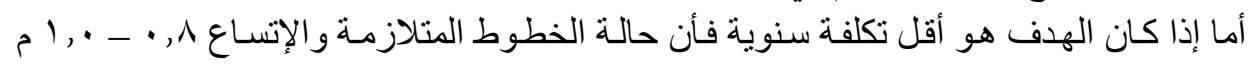

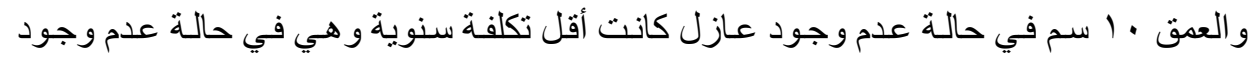

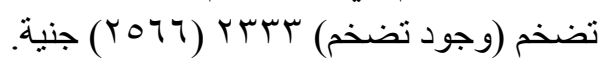
ولذا يمكن التوصية في حالة عدم إستخدام الحاجز تحت سطحي بعمق خطوط التتقيط تحت السطحية

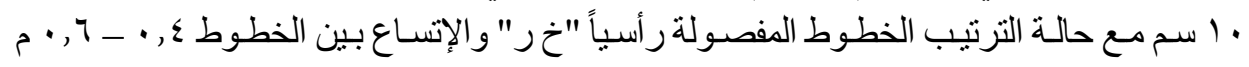
وظللك للطماطم و البصل.

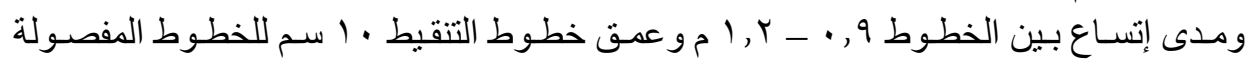

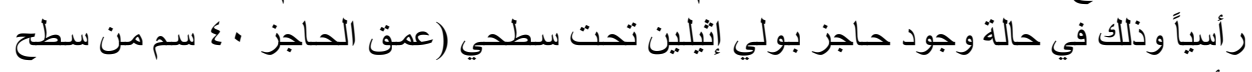
الأرض) لمحصول الطماطي.

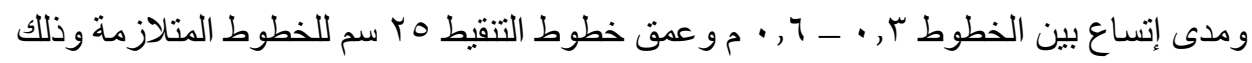
في حالـة وجـود حـاجز بـولي إثيلين تحت سطحي (عمق الحساجز 00 سـ مـن سطح الأرض)

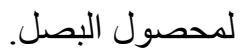

